\title{
Enhancing Flood Resilience and Climate Adaptation: The State of the Art and New Directions for Spatial Planning
}

\author{
Meng Meng *, Marcin Dabrowski and Dominic Stead \\ Faculty of Architecture and the Built Environment, Department of Urbanism, \\ Delft University of Technology (TU Delft), Julianalaan 134, 2628BL Delft, The Netherlands; \\ m.m.dabrowski@tudelft.nl (M.D.); D.Stead@tudelft.nl (D.S.) \\ * Correspondence: m.meng@tudelft.nl; Tel.: +31-639-108-103
}

Received: 3 August 2020; Accepted: 17 September 2020; Published: 23 September 2020

check for updates

\begin{abstract}
The need to respond to increasing flood risk, climate change, and rapid urban development has shaped innovative policies and practices of spatial planning in many countries over recent decades. As an instrumental-technical intervention, planning is mainly used to improve the physical environment (through concepts such as regulating waterproof facades of architecture, setting buffering zones, and designing green-blue corridors). However, the implementation of the proposed physical interventions is often challenging and necessitates assistance from practices such as climate assessment, policy disciplines, civil societies, and economic resources. These extensive perspectives have spawned many new research domains in the realm of spatial planning. This paper provides a review of the recent developments in flood resilience, risk management, and climate adaptation; based on this, it positions planning research and practice within these works of literature. Four clusters of thought are identified, mainly in the European and American scholarship of the last two decades. They are environmental concerns, disaster management concerns, socio-economic concerns, and institutional concerns. Current planning research concentrates on disaster management in the underlying belief that planning is functionally efficient. The attention to environmental concerns, socio-economic concerns, and institutional concerns of planning research remains insufficient but has been growing. This, in turn, enlarges the scope of planning research and indicates future directions for study. These new concerns relate to spatial planning's ability to operate effectively in a multi-sectoral setting, despite limited resources and in the face of uncertain risk.
\end{abstract}

Keywords: flood resilience; spatial planning; flood risk; literature review

\section{Introduction}

There are lively scholarly and policy discussions on how to solve the growing flood threat and climate change, on what approaches are usable, and on how different actors can contribute to addressing these concerns [1-4]. Although spatial planning has been recognised as a source of useful tools to handle flooding hazards, most studies appraise its physical function, as an instrumental-technical intervention to arrange spatial layout and land use, such as regulating waterproof facades of architecture, setting buffering zones, and designing rainfall gardens and green-blue corridors [5-7]. This paper argues that the role of planning goes beyond this. To support it, the paper reviews a wide range of literature to (1) outline the state of the literature dealing with floods in policy, research, and practice based on multiple disciplines, and (2) position the domain of spatial planning in the different parts of the literature. This paper concentrates on three types of flooding events: (1) fluvial floods (or river floods), (2) pluvial floods (or surface water floods occurring when rainfalls exceed the capacity 
of drainage systems), and (3) coastal floods (including extreme storm surges and gradually rising sea levels).

The remainder of this paper consists of four sections. Firstly, it introduces a four-pillar conceptual framework for the literature review developed in this paper. Secondly, it applies this framework to review the literature of relevance in the recent 20 years (the 1990s-late 2010s). We provide a brief account of the genesis of each pillar and characterize what is distinctive about their approaches to environmental, disaster management, social-economic, and institutional problems. The objective here is to outline a broad landscape of scholarship from across various disciplines over which the position of the planning field can be understood and clarified. Thirdly, the paper explores the status quo in the spatial planning research in relation to each of the four clusters of thought to identify the well-developed and neglected perspectives, the latter creating scope for planning to contribute to the advancement of scholarship on flood resilience. The paper closes with an outline of future research directions and concluding remarks.

\section{The Four Pillars of Resilience Agendas through the Lens of Sustainability}

The literature integrating resilience and sustainability into urban development provides a heuristic way of rethinking the building blocks of flood agendas. In the latest 17 Sustainable Development Goals (SDGs) for 2030, UN members associate resilience with sustainability in Goal 11 and propose to "make cities and human settlements inclusive, safe, resilient, and sustainable." [8] The efforts envisaged to reach this goal are diverse and can be summarised into five perspectives, including environmental concerns (the reduction of the adverse environmental impact of cities), social concerns (the protection of poor or vulnerable people, including women, children, and elderly people), economic concerns (the decrease in financial loss), disaster management concerns (access to safety through, for instance, transport infrastructure and resilient buildings), and institutional concerns (participatory and integrated planning and management). A similar idea appears in Grafakos, Gianoli and Tsatsou's research [9]. They developed a framework for the assessment of sustainability and resilience projects in terms of environmental benefits (e.g., land, water, climate change), social benefits (e.g., safety, risk reduction, welfare), economic benefits (e.g., recourses, payments), and institutional and governance benefits (e.g., stakeholders, institutions, networks).

Inspired by this, we propose a four-pillar framework to review the research, practice, and policy experience on the nexus between flood resilience and spatial planning. These pillars are (i) environmental, (ii) disaster management, (iii) socio-economic, and (iv) institutional (and governance) concerns. Social and economic perspectives are merged on account of the intertwined negative impacts caused by floods, for instance, the poor (a financial problem) having limited access to safe shelter (an inequity problem). A disaster management perspective is highlighted here referring to physical interventions (e.g., infrastructure layout designs, land use allocation) and their related regulations allowing physical changes (e.g., building codes), which are both closely associated with spatial planning.

\section{The Genesis of Policies, Studies, and Practice to Address Flooding}

Based on the four pillars outlined above, this section provides a brief account of the genesis of policies, academic studies, and practices to address flooding. It is based on extensive (academic and grey) literature across the fields of climate science, disaster mitigation, water management, flood risk management, hydrological engineering, economics, adaptation planning, public participation, administration, and governance.

\subsection{Environmental Concerns}

The literature focusing on environmental concerns aims to unpack how social-ecological systems-encompassing all ecological goods, (built) assets, services, and even populations-are threatened by flood hazards that can be exacerbated by climate change and human activities. 
These concerns arose from the uncertainty of climate change, extreme weather, and the risks they entail. At the global level, this strand was promoted by the ecosystem-based risk projection, proposed by the Intergovernmental Panel on Climate Change (IPCC). As early as in the 1990s, the IPCC started to assess the impacts from climate change and extreme weather based on several presumed scenarios in terms of the increase in $\mathrm{CO}_{2}$ emissions, global mean temperature, precipitation, and sea-level rise [10]. In 2001, scientific progress accelerated in the Third Assessment Report (TAR), when new observations and the related modelling (for instance, greenhouse gases, solar activity, and land surface properties) were integrated. This inspired many studies to use a similar approach in climate impacts assessment, "beginning with projections of future emission trends, moving to the development of climate scenarios, and thence to biophysical impacts studies" [11].

The climatic assessment also inspired the efforts to identify gains and losses of flood-exposed entities in different regions, nations, and areas [12-18]. In this trend, the IPCC Third Assessment Report (2001) [19] initiated human-security-based assessment and brought about the notion of vulnerability. As a result, contextual conditions were gradually used to analyse "the degree to which a system is susceptible to, or unable to cope with, adverse effects of climate change, including climate variability and extremes" [19], considering wealth, technology, information, skills, infrastructure, access to resources, and management capacities [11,20-22].

Climate impacts on ecosystems, (built) assets and human security are then visualised in climate-sensitive maps, flood-exposure maps (fluvial, pluvial, and coastal floods), and vulnerability maps. These maps contribute to an exchange of the prediction of the scale, time, location, and likely damages of impending floods $[13,14,21]$. They further help to provide information for setting priorities in climate-resilience activities in disaster management, for instance, risk-based education, emergency forecasting, early warning, mitigation, prevention, preparation, and post-recovery [23-25] (see Section 3.2).

\subsection{Disaster Management Concerns}

The literature focusing on disaster management concerns aims at identifying effective solutions to reduce the negative impacts of flood hazards. Since the early 2000s, this cluster witnessed a transition from hydrological engineering defences toward integrated flood risk management, considering the increasing damage potentiality in a basin where confidence in safety is miscreated by traditional flood control infrastructure $[3,26]$.

The notions of 'disaster cycle' or 'flood risk cycle' inspired this transition, which called for attention to the consecutive phases of flood events (before, during, and after) $[27,28]$. Numerous resilient measures were developed in this context, such as prevention, protection, response, and recovery, even though they were interpreted differently in diverse models [1,29-31] (See more details in Table A1 in Appendix A).

The implementation of the proposed measures, however, often faced challenges, given the enormous investment entailed, as well as data and predictive uncertainty in modelling [3]. Additionally, current successful solutions may no longer be useful when hazards exceed a threshold (the maximum capacity of a system to keep safety, e.g., drainage systems) in the future. Thus, static or on-off resilient measures are not advisable in the face of the unpredictability of climate change, and the flexibility to shift from one to another alternative is significant [32-35]. Last but not least, there might be cases where not all adaptation options need to be implemented immediately in the short term, and the awareness, risk evaluation, and even technical support also need time to be prepared [36,37].

Consequently, recent literature since the 2010s has gradually turned its attention to the assessment of the validity and pathways of the proposed resilience measures, which calls for a dynamic and adaptive method to offer options identification, options selection, and options implementation [38]. Thus, a series of studies have been developed to help decision-makers and practitioners to (1) arrange investment and time in a sequent way, (2) identify the thresholds or scenarios for a system's (nation, region, city, area) reliance on alternatives, (3) determine the decision points (and the conditions) to lead the preparation for the alternatives, and (4) portray future trajectories of implementing a mix of 
resilient alternatives [39]. The consideration of the economic efficiency of resilient measures and wise allocation of funding has been raised in this part of the literature, consolidating the strand of research focusing on socio-economic concerns (see Section 3.3).

\subsection{Socio-Economic Concerns}

Despite the growing knowledge on the effects of climate change and flood hazards and available measures to deal with the effects, substantial economic uncertainties still hinder the design and implementation of adaptation measures in practice. These uncertainties include: (1) the potential loss of threatened systems under pressures [19], (2) the extent to which the resilient (or adaptation) measures could ameliorate the negative effects and enhance positive effects, and the extent of the cost of actions [40-42], and (3) the distributional effects of the proposed resilience measures [43]. Correspondingly, the literature focusing on socio-economic concerns, supported by economic scientists and economic analysis institutions, provides some insights into these issues by (1) estimating financial losses of climate change and flood hazards [44], (2) calculating investment and payoff of flood resilience measures [45], and (3) allocating the responsibilities of a flood (or pre-flood) loss compensation [46].

Initial studies from the IPCC's 2001 report [19] and The Stern Review on the Economics of Climate Change [44] have made attempts to use formal economic models to estimate the global costs and risks of climate change on markets (e.g., agriculture), no-market conditions (e.g., human health), and social contingencies (e.g., migration). Their findings indicated a more sensitive economic structure of developing countries [19] and a 5-20\% decrease of GDP each year globally in the case that no action is taken, and the temperature continues to increase [44]. Following a similar route, increasing economic studies formulated models to assess the effects of climate change and the damages of floods to agriculture, residential areas, properties, etc., according to different land use functions either at regional, local, or sectoral levels [47-49].

The literature calculates investment and payoff aims to assess the economic effectiveness of flood resilience options and compare alternatives. Generally, measures and projects dealing with climate change and floods can be expensive; governments and institutions have to carefully consider how to deploy limited funding [50]. Cost-benefit analysis (CBA), cost-effectiveness analysis (CEA), and multi-criteria analysis (MCA) have been three primary evaluation tools widely used to measure flood damages, project costs, and net benefits [51-53]. These tools create opportunities to explore the costs for non-resilience or non-adaptation initiatives, the benefits brought by a potential resilience choice, and the factors that should get priority considering a limited budget (e.g., the macro-economic effects, the losses in production, or the human suffering accompanying a flood) [50].

The flood (and pre-flood) loss compensation focuses on the fair distribution of adverse effects of flood risk management. This is based on the notion that actions to prevent floods, like flood defence, water retention, and planning for adaptation, can also bring about loss. It could occur when flood risk management measures are taken to protect a part of a region or an area (normally densely populated), while another group of people is left out under the threat of floods (for instance those living in deprived areas). In a flood control project, people and lands with a higher income/value can attract more resources for damage reduction and security protection compared to the poor with degraded land values [43].

Adverse effects of flood risk management could also occur when the construction of flood resilience infrastructures has to expropriate private properties. It leads to a debate on who should pay for private landowners' losses when individual interest is challenged by public interests. The burden-sharing and benefit-giving, in the European context at least, follow four major principles [46]: (1) the solidarity principle (for instance, all Dutch citizens pay for the cost caused by flood risk management via tax and leave responsibilities to regional water boards and the Dutch state), (2) the protection of private property rights principle unless for public interests with authorised law, the appropriate ministry's approval, and compensation (e.g., in England), (3) the equity before public burdens principle (compensations to a 
restricted loss in the public interest in Flanders), and (4) the practice of citizens bearing minor adverse effects themselves while getting compensation in the case of strong adverse effects (e.g., in France).

\subsection{Institutional and Governance Concerns}

The strand of the flood resilience scholarship concerned with institutional and governance issues is a mixed body of literature spanning across the disciplines of social science [54], political science [55], and policy studies [56,57]. It concentrates on exploring how an institutional system, at the national, regional urban, or community level responds to flood risk and natural hazards.

This literature has been built on the observations that resilience policies and adaptation activities are a result of the collective behaviours in multi-level, multi-domain, and multi-actor settings [56-58]. Public agencies and non-state actors, within a system or between systems, adjust their structures and practices, interact with each other and carry out procedures, routine, norms, and conventions in a specific political context. The weaknesses in institutional and governance features, such as human resources, social and economic capital, access to information and resources, and flexibility in decision-making processes, could hinder the systems' adaptive capacity to deal with climate change and the flood risk [59-66]. The United Nations' Inter-Agency Secretariat of the International Strategy for Disaster Reduction (UN/ISDR) interpreted this capacity as "a combination of all the strengths and resources available within a community, society or organisation that can reduce the level of risk or the effects of a disaster" [67].

Numerous studies have examined—often interrelated—institutional and governance barriers for resilience [54,56-58,68-74] (See Table A2 in Appendix A). The barriers, initially, reside in policies, strategies, and project plans. Studies regarded them as the outputs of governance process through a co-determined interaction on the one hand; and on the other hand as the rules and directions to influence policymakers, practitioners, and civil society's working styles in following governance process [75-77]. New ways of framing resilience in these documents raise the discussions on whether to choose to incorporate it in a detached sectoral paper or mainstream it with other local agendas; how to deal with the mismatches between different governance levels caused by new framing; and how to realise the ambitions of new framing by balancing the conflicts between short-term economic benefits and long-term climatic benefits $[54,56,57,71,73]$.

Quite a few papers attribute institutional barriers to the complexity of the collaborative process in flood governance. Individual institutions or agents with different roles, interests, and leadership form a related social network in flood agendas. Such divergence can result in difficulties in building consensus between the public and private actors $[56,57,73]$. The difficulty can be further complicated by the distinctive policy-making procedure features between horizontal and vertical governmental sectors such as frequencies, cycles, and workflows [56,57,70-72].

The studies on authority, resources, and organisational conditions partly respond to the debate on how to facilitate policy-making and sectoral collaboration in flood governance. In a nutshell, this requires legal support, influencing powers, clear responsibilities of the different organisations involved, discretions, sufficient financial resources, accessible information and knowledge on climate change impacts and hydrological issues, proactive political wills, inclusive participation of stakeholders, skilled personnel, and innovative techniques [54,56-58,69,74].

Last but not least, a few institutional research papers regard deeply rooted contextual factors as a source of institutional barriers, given how those factors shape governance conditions. As Harries and Penning-Rowsell [78] identified, institutional cultures, and established public perceptions could impair the agents' capacities to embrace extensive resilient measures, given that the stickiness to institutional routine and widely accepted notions are often unchangeable. Similar ideas are also advanced in studies from Simanjuntak et al. [71], Bulkeley [57], and Parsons et al. [68], which extend the barriers to the history- and culture-embedded institutional notions, values, and traditions (e.g., social expectations, legislation, and juridical decisions values) and institutional features such as administrational procedures, laws, and organisational structures which are relatively enduring and hard to change. 


\subsection{Summary and Discussion}

As outlined above, studies of flood resilience tend to fall into four groups (Figure 1). Even so, it is notable that these four pillars of the literatureclosely interact with and complement each other. Environmental concerns literature focuses on the adverse impacts of climate change on social-ecological systems and identifies the vulnerability of ecological assets, built assets, services, and populations based on observation, modelling, projection, and assessment. The findings from this strand of literature have attracted the attention of international, national, and sub-national institutions to the need for making agreements to develop climate coping strategies. Then, the literature concerned with disaster management put forward the need for integrated resilient measures to deal with flood events. Among the proposed measures, specific options were chosen and implemented in flexible pathways according to the local context. The literature on socio-economic concerns consolidated the options' selection and pathway implementation on account of investment, payoff, and compensation, as well as the understanding of the losses generated by climate change and the flood risk in case of lack of adaptation action. The abovementioned activities were all influenced by institutional and governance features, for instance, existing policies, agencies, political conditions, and history- and culture-embedded perceptions, as highlighted in the strand of the literature on institutional and governance concerns.

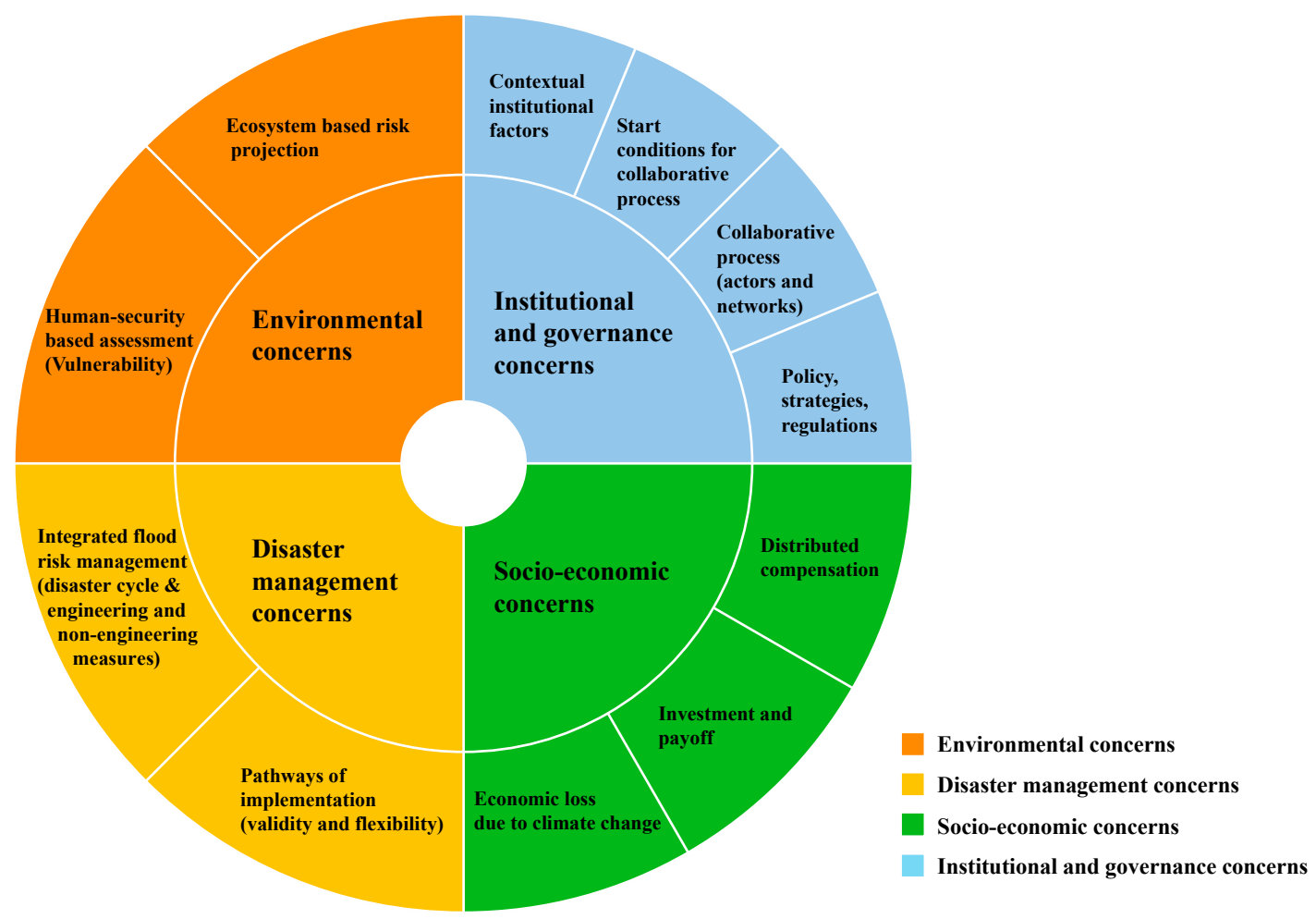

Figure 1. The four pillars in the literature on flood resilience.

\section{The Development of Spatial Planning Research, Policy and Practice Across the Four Pillars of the Flood Resilience Literature}

This section explores the development and challenges of spatial planning in relation to the proposed four pillars of the flood resilience and the abovementioned disciplines, based on the literature from spatial policy, land use planning, urban studies, flood risk management reports, and water management studies. It will be argued that spatial planning research concentrated on disaster management concerns, despite the emergence of planning research, policy, and practice on environmental, socio-economic, and institutional and governance concerns. Here, the subtle difference between spatial planning and similar terms like land-use planning or urban planning is neglected for simplification. Some early 
research has indicated that these similar terms are more technical and concerned with zoning and setting parameters for land development, while spatial planning is broader, not only technical but also relating to the coordination of spatial activities $[79,80]$.

\subsection{Limited Attention Paid to Environmental Concerns}

Environmental concerns have not been a main focus of the planning scholars and practitioners. In practice, agencies dealing with climate science, meteorology, environmental science, and hydrology are forerunners in flood resilience, having more experience in monitoring, weather forecasting, and climatic assessment. As a result, these agents are mainly responsible for the observation, modelling, and projection of climate change impacts and their leading flood events. For instance, in the UK, the Environment Agency in England, the Natural Resources Wales, the Scottish Environment Protection Agency, and the Department of Infrastructure in Northern Ireland launched their flood maps within their jurisdictions [81-84]. Similarly, in the Netherlands, the Foundation Climate Adaptation Services launched the Climate Impact Atlas, which indicates the potential flooding areas [85].

Planning institutions, due to a lack of professionalised knowledge, often step behind the abovementioned institutions. Even so, they can still make a contribution to this stream by building strategic cooperation with those forerunners and overlaying hydrological maps (e.g., flooding maps) with socio-spatial data (e.g., age, incomes, land uses) to identify gains and losses of flood-exposed entities in different regions, nations, and areas. The findings then provide opportunities for the planning sector to offer solutions to reduce flood loss (more details in Section 4.2). Typical cases are the Urban Waterfront Adaptive Strategies in New York [86] and Climate Change Adaptation Strategies in Rotterdam [87], in which flooding maps and socio-spatial data were used to identify the vulnerabilities of communities and neighbourhoods caused by coastal floods and rainfalls and further develop strategies for flood resilience.

\subsection{A Focus on Disaster Management Concerns}

According to our observations, extensive planning literature has developed rich experience in disaster management concerns. The main aim of this literature is to identify and implement measures that planning can use to deal with floods. As with the former goal, the proposed measures in the more recent literature since the 1990s can be categorised into five aspects, based on the early study from Hegger et al. [88], including avoidance, defence, mitigation, preparation, and recovery in terms of structural and non-structural interventions (see details in Table 1). However, these measures can be debatable and are not universally used. For instance, floodplain zoning plans in the avoidance category, which suggest retreating from waters (often coastal and fluvial floods), have faced criticism of losing valuable lands for urban development in countries and areas with high population density, like those that are members of the Organisation for Economic Cooperation and Development (OECD) [89,90]. Another case is the synergy of dyke systems and transportation or residential development in the defence category. This synergy has been a context-specific experience, for instance, in the Netherlands, where the integration between planning and flood risk management and un-embanked area development (urban development beyond dykes) is well-established and rooted in deeply embedded traditions in water management and planning [91,92]. Thus, these experiences cannot be used in other contexts without modification.

Nature-based infrastructure for flood mitigation has been a major solution widely promoted in the planning literature to decrease flood loss. Ecological buffer zones at the macro-scale; mangroves, dunes, mashes wetlands, lakes, and green-blue river/waterway/canal branches at the mezzo-scale; and rain gardens, permeable paving, green roofs at the micro-scale are proposed to protect shorelines, retain rainwater and ensure drainage of excessive river waters as fast as possible [89,93,94].

Preparation and recovery measures in the planning literature have not been much explored, such as evacuations and safe haven creations (emergency response). A few papers based on Geographic Information System (GIS) methods, transportation, and urban simulation, opened windows for 
the domain of spatial planning to optimise evacuation plans and shelter locations arrangements in the face of coastal and fluvial floods [95-98]. Similarly, critical infrastructure protection is an under-researched issue in planning literature, which calls for paying more attention to protecting critically important buildings in the flood events, such as power generation plants, healthcare centres, and police stations $[89,99]$.

The literature stressing the implementation and pathway of flood resilience leads to the rise of the notion 'adaptive planning' in the spatial planning literature. This strand of literature calls for (1) planning to keep options open to changing circumstances, avoiding locking in rigid decisions; and for (2) local societies and policymakers to remain flexible and adjust their strategies and measures in the face of the uncertainty of floods and climate change $[100,101]$. While 'adaptive planning' is a well-established notion in climate change discourse or flood risk management, it remains a conceptual metaphor in the planning field mostly, used to explore how to implement a sequence of proposed measures dynamically over time. A crucial part of this literature is to define the overall adaption measures and the future conditions (threshold) determining alternative options to replace the unsuccessful measures [100-103]. This literature has been criticised due to its difficulty in defining successful and unsuccessful measures and the idealised assumptions that decision-makers would like to make decisions based on long-term visions and seek opportunities to adjust plans and strategies in the face of the failure of some measures or their unintended negative effects ('maladaptation') [104]. 
Table 1. Five types of measures to deal with flood risk when planning is taken into consideration.

\begin{tabular}{|c|c|c|c|}
\hline Measures & $\begin{array}{l}\text { Statements in Planning } \\
\text { Policies/Regulations }\end{array}$ & Affected (Non-) Structural Interventions in Practice & References \\
\hline Avoidance/prevention & $\begin{array}{l}\text { Floodplain zoning plans; land acquisition } \\
\text { and relocation plans }\end{array}$ & $\begin{array}{l}\text { Watershed management and retreating from waters (avoiding urban } \\
\text { development in flood-prone areas) } \\
\text { - Function arrangement (economic enterprises, residential areas } \\
\text { and recreations) } \\
\text { - } \quad \text { Population move and building (re)locations }\end{array}$ & {$[89,94,105]$} \\
\hline Defence & $\begin{array}{l}\text { Multi-purpose/multifunctional engineering } \\
\text { measures to deal with coastal and fluvial } \\
\text { floods with the consideration of leisure, } \\
\text { landscape, and commerce }\end{array}$ & $\begin{array}{l}\text { - Dykes, floodwalls or quay walls (setting back, combined with residential } \\
\text { buildings, commercial development, greening, and transportation) } \\
\text { - } \quad \text { Reservoirs (water storage, supply, natural landscape, and recreation) }\end{array}$ & [91-93] \\
\hline Mitigation & $\begin{array}{l}\text { Nature-based infrastructure for coastal } \\
\text { flooding reduction, rainfalls detention and } \\
\text { retention, and river discharge passage }\end{array}$ & $\begin{array}{l}\text { - } \quad \text { Creation of green buffers and flood detention areas } \\
\text { - Creation and preservation of mangroves, dunes, mashes wetlands, lakes, } \\
\text { and green-blue corridors } \\
\text { - } \quad \text { Waterways and channels de-culverting, greening, and improvement } \\
\text { - } \quad \begin{array}{l}\text { Sustainable Drainage Systems (SuDS)/Low impact development } \\
\text { measures (rain gardens, permeable paving, green roofs) }\end{array}\end{array}$ & {$[89,93,94]$} \\
\hline Preparation & $\begin{array}{l}\text { Building codes and building controls; } \\
\text { evacuation plans; safe havens arrangement }\end{array}$ & $\begin{array}{l}\text { - Buildings waterproofing (removable stop logs, water-retaining walls, } \\
\text { mobile barriers, the lowest flood elevation for footings, structural } \\
\text { requirement to withstand water pressure, prohibiting basements, } \\
\text { flood-proof facades, standards for buildings anchored to foundations) } \\
\text { - Road networks optimization } \\
\text { - Safe havens creation }\end{array}$ & {$[92,95-97,106]$} \\
\hline Recovery & $\begin{array}{l}\text { Post-recovery plan; critical infrastructure } \\
\text { protection }\end{array}$ & $\begin{array}{l}\text { - } \quad \text { Building reconstruction } \\
\text { Re(location) and reinforcement of supporting buildings such as power } \\
\text { plants, healthcare centers, and police stations }\end{array}$ & {$[89,99,107]$} \\
\hline
\end{tabular}




\subsection{A Weak But Emerging Focus on Socio-Economic Concerns}

The discussion of socio-economic features of resilience measures has been largely neglected in the planning literature. It has been covered only in a few papers concentrating on the calculation of investment and payoff of flood resilience measures in urban development projects [108]. An early study from Bruin and Goosen [109] used cost-benefit analysis (CBA) to verify the economic efficiency of flood resilience measures to deal with precipitation. They found that rainfall gardens, raised roads, and building codes were not economically efficient in contrast to ecological networks in a Dutch case. The institute Urban Floods Community of Practice confirmed the significance of regulatory instruments in Florida relying on cost-effectiveness analysis (CEA), where risk-based building codes reduced severe flood loss from Hurricane Charley by 42\% [110]. Similar applications of cost-effectiveness analysis also appear in papers which confirm the effects of zoning plans and development controls in England, Colombia, Japan, New Orleans, Seoul, etc. [110]. Raaijmakers et al. explored ways of using multi-criteria analysis (MCA) to decide either a continuation of housing development in flood-prone areas for profits or a change of cultivated lands to natural lands to face the flood risk (coastal floods caused by storms) given the public and private stakeholders' worries and their individual risk perception [108].

Economic reports have given a more critical assessment of different flood resilience options available for planning and pointed out that the benefit-to-cost ratio is variable. For instance, mangroves as a natural option to create buffer zones to reduce coastal floods, supposed to have a high benefit-to-cost ratio by the Economics of Climate Adaptation Working Group (ECA) report [2], was criticised by Sanghi et al. [111] on account of an exponential increase in costs in high-income countries, like the United States. Similar discrepancies also appeared in options like retreating from low-lying areas, and building codes (see Table 2). The inconclusive cost-benefit results are partly due to the uncertainties related to flooding extremes and the high site-specificity [90]. The same measures adopted in different areas can have different ratios of cost and benefit due to the specific features of an area, from land prices, policy enforcement costs, to maintenance expenses, differences in risk levels, the costs of resilience measures, existing costs, and asset lifetimes, etc. [111,112]. Also, the calculation can be affected by the definition of 'cost' and 'benefit' which can greatly alter the mathematical results [90,111]. Such a site-based uncertainty is, thus, a reason which makes scholars unable to agree on the economic efficiency of resilience measures. Even so, the analysis in the economic literature still provides insights for the planning literature on how to calculate the economic payoffs and profits of resilient measures that support option selection according to local conditions. 
Table 2. Economics of flood resilience measures available for spatial planning.

\begin{tabular}{|c|c|c|c|c|}
\hline \multicolumn{2}{|c|}{ Resilience Interventions } & \multirow{2}{*}{$\begin{array}{l}\text { Calculation Methods } \\
\text { CBA }\end{array}$} & \multirow{2}{*}{$\begin{array}{l}\text { Findings } \\
\text { A high benefit-to-cost ratio for hurricane } \\
\text { protection and storm-surge; yet involving high } \\
\text { opportunities in costs of lands, like OECD } \\
\text { countries }\end{array}$} & \multirow{2}{*}{$\begin{array}{c}\text { References } \\
{[2,90]}\end{array}$} \\
\hline $\begin{array}{l}\text { Watershed management and } \\
\text { function arrangement }\end{array}$ & Retreating from low-lying areas * & & & \\
\hline & $\begin{array}{l}\text { Zoning plan with a } \\
\text { functional arrangement }\end{array}$ & CEA & High benefits & [110] \\
\hline & $\begin{array}{l}\text { A change of cultivated lands to natural } \\
\text { lands to mitigate loss }\end{array}$ & MCA & $\begin{array}{l}\text { High acceptance of public and private } \\
\text { stakeholders in individual risk perception }\end{array}$ & [108] \\
\hline & Mobile barriers * & CBA & A high benefit-to-cost ratio & [2] \\
\hline \multirow[t]{3}{*}{ Building codes/controls } & $\begin{array}{l}\text { Houses with waterproof glass } \\
\text { or windows * }\end{array}$ & CBA & A low benefit-to-cost ratio & [109] \\
\hline & $\begin{array}{l}\text { Retrofitting building materials } \\
\text { against floods * }\end{array}$ & CBA & $\begin{array}{l}\text { High/low benefit-to-cost ratio depending on } \\
\text { differences in risk levels, the costs of resilience, } \\
\text { existing costs and asset lifetimes, and assumed } \\
\text { discount rates locally }\end{array}$ & [112] \\
\hline & $\begin{array}{l}\text { Residential building controls reducing } \\
\text { severe flood loss from Hurricane } \\
\text { Charley by } 42 \%\end{array}$ & CEA & High benefits & [110] \\
\hline $\begin{array}{l}\text { Multi-purpose engineering } \\
\text { measures }\end{array}$ & $\begin{array}{l}\text { Construction of dykes combined } \\
\text { with transportation }\end{array}$ & CBA & A low benefit-to-cost ratio & [109] \\
\hline \multirow[t]{2}{*}{$\begin{array}{l}\text { Natural coastal and waterfront } \\
\text { buffer zones }\end{array}$} & $\begin{array}{l}\text { A change of cultivated lands to } \\
\text { ecological networks }\end{array}$ & CBA & A high benefit-to-cost ratio & [109] \\
\hline & Mangroves * & CBA & $\begin{array}{l}\text { A high benefit-to-cost ratio; yet an } \\
\text { exponentially increase in costs due to land } \\
\text { transformation and policy enforcement costs in } \\
\text { high-income countries, like the US }\end{array}$ & {$[2,111]$} \\
\hline $\begin{array}{l}\text { Water detention base on } \\
\text { green space }\end{array}$ & Rainfall gardens for water storage & CBA & A low benefit-to-cost ratio & [109] \\
\hline
\end{tabular}

CBA: cost-benefit analysis; CEA: cost-effectiveness analysis; MCA: multi-criteria analysis. ${ }^{*}$ The findings come from economic reports and studies. Grey-coloured blanks are the findings indicating variable benefit-to-cost ratios. 


\subsection{An Increasing Focus on Institutional and Governance Concerns in the Planning Literature}

A small but increasing number of planning researchers focus on institutional and governance concerns [113-117], inspired by the knowledge provided by social scientists, political scientists, policy scientists, and policymakers. One strand of the literature suggests exploring the involvement of planning in flood affairs as a by-product of water management governance under the notions such as 'integrated water resources management' [118], 'synergy between flood risk management and spatial planning' [89,119-122], 'multi-level governance and boundary spanning planning for adaptation' [123], and 'diversification of flood risk management with spatial planning's involvement' [122]. Another strand of research, although represented only in a few papers, positions planning at the centre of flood resilience and calls for the incorporation of flood risk management and climate adaption in land use planning or spatial planning [113-117].

These emerging studies share a focus on identifying the facilitators and barriers for planning to play a meaningful role in the flood governance and exploring how and why they emerge. The main points in relation to preparation for adaptation (knowledge), vulnerability assessments, adaptation strategies identification, adaptation options selection, and implementation include (Table 3):

1. Governance products: Some studies reported that policies, strategies, codes, standards, and planning rules provided legal supports and incentives for planning to be involved in flood agendas [124]. Empirically, the literature concentrated on systematic integration of resilience or adaptation agendas into planning programmes, policies, and projects [119], a necessity of functioning tools with more stringent and detailed requirements in the national and regional policies to guide policymakers and planners at lower tiers of government [122,125], and the inclusion of climate information and vulnerability assessment in long-term policy decision-making [114]. The solution to those challenges, as Wilby and Keenan [124] argued, often rests in the collaboration process between multiple stakeholders across policy sectors and levels of government.

2. Collaborative process: Increasing numbers of planning studies stress the joint work between planning and extensive actors in the formulation and implementation of resilience and adaptation policies, albeit pointing out that trade-off between governments, planning agencies, hydrological engineers, scientists, civil society, and markets are difficult $[114,117,122,126]$. A few papers added to this line of argument and reported that mismatches in time-spans and procedures between professions could impair the transboundary cooperation between the planning sector and other sectors $[118,120,127]$. More research is needed to explore the reasons and solutions to overcome this mismatch.

3. Start-conditions for planning to participate flood governance: A small number of studies have cast light on the complexity of the collaborative process in terms of authority, resource and organisation conditions and indicated these pre-sets could affect planning's performance in the collaborative governance $[115,116,122]$. For instance, the legal certainty and flexibility of planning tools could influence legal restrictions in land use and policy changes for climatic uncertainty $[115,116,122]$. Also, suitable allocation of finance and access to information in relation to planning is required to deal with distributional effects of floods (fairness), information sharing between sectors, and the public's right to be informed [122,128]. Last but not least, the establishment of technical co-working platforms, clarification of planning's accountability (or responsibilities), and the planners' knowledge determine the planning agencies' capacities in flood governance [114,115,119,120,122].

4. Contextual factors shaping the start conditions for planning in flood governance: This strand of research on the contextual factors that could affect the pre-conditions for planning in flood governance-from the fixed administrative structures and shared perceptions, to notions, values, and traditions embedded in history-is limited in the planning literature. Early studies reported that fragmented structures in political administration, asymmetries of powers, and persistence in the old paradigms in flood governance could hinder planning agencies in implementing a broader set of adaptation measures in flood agendas $[115,119,121]$. However, the means to address these challenges relating to contextual conditions remain an under-researched issue. 
Table 3. Key challenges for planning to play a role in flood governance.

\begin{tabular}{|c|c|c|c|}
\hline Key Topics & Sub-Topics & Challenges for Spatial Planning & References \\
\hline Outputs of flood governance & $\begin{array}{l}\text { Policies, strategies, codes, standards, } \\
\text { planning rules }\end{array}$ & $\begin{array}{ll}- & \text { Mainstreaming flood risk issues in local agenda } \\
- & \text { Diversifying adaptation measures in discourse such nonstructural measures } \\
- & \text { Aligning the mismatches between local, regional, and national policy discourse } \\
\text { - } & \text { Short-term vs. long-term benefits }\end{array}$ & {$[114,119,122,125]$} \\
\hline \multirow{2}{*}{ Collaborative process } & Actors/stakeholders & $\begin{array}{l}\text { Enhancing the roles of planning in the decision-making process (proactive participation) } \\
\text { - }\end{array}$ & {$[114,117,122,126]$} \\
\hline & Networks & $\begin{array}{l}\text { - Aligning the conflicting time-spans and planning procedures in contrast to water } \\
\text { management and environmental planning } \\
\text { Strengthening communications and cooperation between governmental and private actors } \\
\text { in planning and flood-risk management }\end{array}$ & {$[118,120,127]$} \\
\hline \multirow{3}{*}{$\begin{array}{l}\text { Start conditions for planning to participate } \\
\text { in flood governance }\end{array}$} & Authority condition & $\begin{array}{l}\text { Balancing legal certainty and flexibility to regulate restrictions or change land-use functions } \\
\text { for flood resilience }\end{array}$ & {$[115,116,122]$} \\
\hline & Resource condition & $\begin{array}{l}\text { - } \quad \text { Adopting appropriate principles in dealing with distributional effects of planning layouts } \\
\text { (fairness in the distribution of cost and benefit), } \\
\text { Enabling information sharing and knowledge communications between } \\
\text { governmental sectors } \\
\text { Facilitating public access to spatial planning information. }\end{array}$ & {$[122,128]$} \\
\hline & Organisation condition & $\begin{array}{l}\text { - Establishing a technical information platform for interactions between territorial, } \\
\text { institutional, and policy cooperation } \\
\text { Clarifying blurred accountability (responsibilities) and powers between national authorities, } \\
\text { local planning actors, and other stakeholders for flood events } \\
\text { Personnel skills }\end{array}$ & {$[114,115,119,120,122]$} \\
\hline \multirow{2}{*}{$\begin{array}{l}\text { Contextual factors shaping the start } \\
\text { conditions for planning in flood governance }\end{array}$} & Institutional design & Facing fragmented administrative and political structures & {$[115,119]$} \\
\hline & $\begin{array}{l}\text { Notions, values, and traditions embedded in } \\
\text { history and traditions }\end{array}$ & $\begin{array}{l}\text { - } \quad \text { Facing the persistence in the old paradigms (institutional inertia and path divergence) } \\
\text { - Facing the asymmetries of powers }\end{array}$ & [121] \\
\hline
\end{tabular}




\subsection{Summary and Discussion}

As a dispensable approach for flood resilience, planning makes a contribution through a broad range of inter-disciplinary experience. Figure 2 shows the recent developments of planning research, policy, and practice influenced by environmental concerns, disaster management concerns, socio-economic concerns, and institutional and governance concerns. The darker the colours are, the deeper the relative exploration by the publications in relation to spatial planning. The four-pillar model indicates that the planning literature pays more attention to disaster management concerns. This reflects the perspective on planning as a design approach, functionally efficient in dealing with floods, which corresponds to one origin of planning as a physical intervention approach organising city development and property.

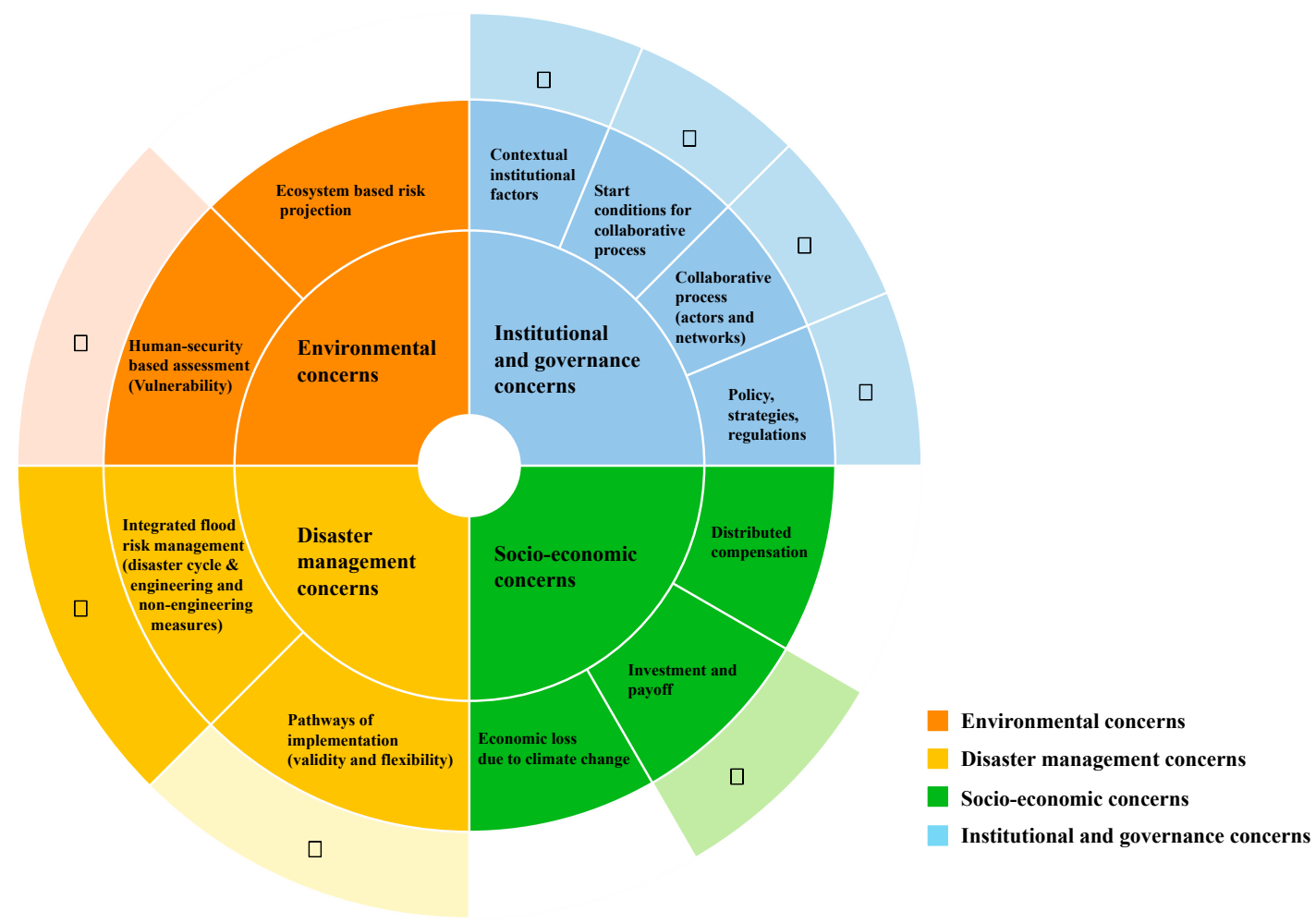

Figure 2. The developments of planning literature in the four pillars (the third ring). Note: The dark colors mean that there are many studies, pale colors mean that there is a limited but increasing amount of studies, and white means that there is a gap here and the topic is under-researched in planning literature.

Meanwhile, the impact of climate analysis, economic analysis, social science, and policy science on planning is emerging, even though there are still few planning studies exploring those concerns. They inspired planning research, policy, and practice to broaden their scopes to include new topics such as vulnerability identification, investment and payoff, and governance. Planning, thus, is adapting its role as an integrated approach to contribute to flood resilience.

\section{Discussion and Concluding Remarks}

The growing threats of floods and climate change necessitate long-term safe, fair, economically efficient, and institutionally coordinated circumstances for human settlements. For this goal, this paper proposes a four-pillar framework to understand environmental, disaster management, socio-economic, and institutional challenges that need to be considered in flood resilience and climate adaptation. It was applied here to conduct an extensive literature review spanning across the fields of climate 
science, disaster mitigation, water management, flood risk management, hydrological engineering, economics, climate policy, adaptation planning, public participation, administration, and governance.

Following that, the proposed framework was used to identify and assess the developments of spatial planning in relation to flood resilience and climate adaptation against the disciplines mentioned above. Our analysis of the literature indicates that the domain of planning concentrates on the improvement of the physical environment mainly in relation to disaster management concerns, in the belief that planning is an instrumental-technical intervention shaping human settlement patterns. However, planning is a broad discipline increasingly including the environmental, socio-economic, and institutional topics in the wider policy context. This trend is spurred by insights from climate change analysis, economic analysis, social science, governance and policy studies, and promoted by pioneering planning scholars.

Our analysis also indicates that emerging topics could bring valuable insights informing the implementation of physical planning in practice, which remains challenging due to uncertainty about the future risks, limited resources, and complex social and institutional relations. Relevant research can add to spatial planning's ability to (1) enhance the evidence-based evaluations and strategies for resilience; (2) act on uncertainty in the face of a shortage of financial resources; (3) address the unfair distributional effects of flood damages with adequate and equitable compensation; (4) manage societal concerns and divergent interests; (5) improve the coordination of resilience measures across sectors and spatial scales; and, finally, (6) propose spatial resilience strategies that respect and take advantage of knowledge and values embedded in local history and traditions.

Author Contributions: This article is the result of the joint work by all authors. D.S. and M.D. supervised and coordinated work on the paper and contributed to conceptualization and theory building. M.D. reviewed and edited the original draft. M.M. conceived, designed, carried out the methods selection, analyzed the data, prepared the data visualization and contributed to the writing of this paper. All authors discussed and agreed to submit the manuscript. All authors have read and agreed to the published version of the manuscript.

Funding: This research received no external funding.

Conflicts of Interest: The authors declare no conflict of interest.

\section{Appendix A}

Table A1 lists three typical models revealing the measures to reduce the negative impacts of flood hazards in terms of the risk cycle. Table A2 reviews the research on institutional mechanisms allowing for effective and efficient (governance) actions in multi-level, multi-domain, and multi-actor settings. 
Table A1. Diverse solutions/strategies for flood resilience based on literature in disaster management.

\begin{tabular}{|c|c|c|c|c|}
\hline Stages of Floods & Before Floods & During Floods & After Floods & References \\
\hline & $\begin{array}{l}\text { Disaster risk reduction: } \\
\text { - } \quad \text { Preventive measures: natural retention, flood } \\
\text { defence, land-use plan, building codes } \\
\text { - } \quad \text { Precautionary measures: insurance, training } \\
\quad \text { exercise, early warning }\end{array}$ & (Emergency) response: emergency measures & $\begin{array}{l}\text { Recovery: relief, rehabilitation, } \\
\text { reconstructions, event documentation } \\
\text { and analysis }\end{array}$ & [31] \\
\hline & $\begin{array}{l}\text { Prevention: avoiding construction of houses and } \\
\text { industries; promoting appropriate land-use, } \\
\text { agricultural and forestry practices } \\
\text { Protection: structural and nonstructural, to reduce } \\
\text { the likelihood of floods or the impacts of a location }\end{array}$ & $\begin{array}{l}\text { Preparedness: informing the population about } \\
\text { flood risks and what to do } \\
\text { Emergency response: developing emergency } \\
\text { response plans }\end{array}$ & $\begin{array}{l}\text { Recovery and lessons learned: activities } \\
\text { helping to return to normal conditions }\end{array}$ & [29] \\
\hline & $\begin{array}{l}\text { Prevention: spatial planning or land-use policies, } \\
\text { insurance Defence: dykes, dams, embankments, } \\
\text { weirs, upstream retention }\end{array}$ & $\begin{array}{l}\text { Mitigation: flood compartments, flood-proof } \\
\text { constructions } \\
\text { Preparedness: warning system, preparing } \\
\text { disaster management, evacuation plans, and } \\
\text { managing floods when they occur }\end{array}$ & $\begin{array}{l}\text { Recovery: reconstruction or rebuilding } \\
\text { plans, compensation, insurance }\end{array}$ & [88] \\
\hline
\end{tabular}

Table A2. Research on institutional mechanisms allowing for effective and efficient (governance) actions in multi-level, multi-domain, and multi-actor settings.

\begin{tabular}{cll}
\hline Key Topics & \multicolumn{1}{c}{ Sub-Topics } & \multicolumn{1}{c}{ Challenges for Resilience and Climate Adaptation } \\
\hline & & References \\
Outputs of flood governance & Official policies/strategies/discourse & $\begin{array}{l}\text { Detached or mainstreamed policies/strategies with other local agendas } \\
\text { (commitment or no commitment) }\end{array}$ \\
& - Fit or mismatch of policy framing between different governance levels & Short-term vs. long-term benefits \\
\hline
\end{tabular}

Actors/stakeholders

Collaborative process
- Roles of governmental and private actors (diversity, participation, experimentation, learning and self-organisation)

- Misaligned interests of parties

- The leadership of the foremost actors/or political entrepreneurs

- $\quad$ Policy-making frequencies, cycles and procedures (horizontal and vertical; government, private, and civil society) 
Table A2. Cont.

\begin{tabular}{|c|c|c|c|}
\hline Key Topics & Sub-Topics & Challenges for Resilience and Climate Adaptation & References \\
\hline \multirow{3}{*}{$\begin{array}{l}\text { Pre-, Start conditions for } \\
\text { governance }\end{array}$} & Authority conditions & $\begin{array}{l}\text { - Legislative support from regional and national levels to promote local } \\
\text { actions (regulatory and procedural support) } \\
\text { Powers, responsibilities and discretions of governmental sectors } \\
\text { (devolution and decentralisation) }\end{array}$ & {$[56-58,69]$} \\
\hline & Resource conditions & $\begin{array}{l}\text { - } \quad \text { Finance support or financial resource exchange } \\
\text { - Information sharing and knowledge communication between } \\
\text { governmental sectors and publicity }\end{array}$ & {$[54,56,57,69]$} \\
\hline & Organisation conditions & $\begin{array}{l}\text { - Political wills to take actions, } \\
\text { - Opportunities for the inclusion of citizen and private sectors } \\
\text { in decision-making } \\
\text { - Skills, knowledge, and capacities to organise climate adaptation } \\
\text { - Emerging of alternative technics }\end{array}$ & {$[54,57,69,73]$} \\
\hline \multirow{2}{*}{$\begin{array}{l}\text { Contextual roots shaping } \\
\text { governance conditions }\end{array}$} & Institutional features by design & $\begin{array}{l}\text { - } \quad \text { Administrations procedures } \\
\text { - } \quad \text { Laws and regulations } \\
\text { - } \quad \text { Organet schemes (allocations) or financial instruments } \\
\text { - } \quad \text { Stakeholder selections } \\
\text { - Transparency and openness }\end{array}$ & {$[57,71]$} \\
\hline & $\begin{array}{l}\text { History and culture embedded notions, } \\
\text { values and traditions }\end{array}$ & $\begin{array}{ll}\text { - } & \text { Fixed costs } \\
\text { - } & \text { Learning effects } \\
\text { - } & \text { Institutional arrangement } \\
\text { - } & \text { Social expectations } \\
\text { - } & \text { Legislation and juridical decisions values } \\
\text { - } & \text { Continuation of mal-adaptations }\end{array}$ & {$[57,68,71,78]$} \\
\hline
\end{tabular}




\section{References}

1. Hegger, D.; Green, C.; Driessen, P.; Bakker, M.; Dieperink, C.; Crabbé, A. Flood Risk Management in Europe: Similarities and Differences between the STAR-FLOOD Consortium Countries; STAR-FLOOD Consortium: Utrecht, The Netherlands, 2013.

2. Economics of Climate Adaptation Working Group (ECA). Shaping Climate-Resilient Development: A Framework for Decision-Making; Economics of Climate Adaptation Working Group (ECA): Washington, DC, USA, 2009.

3. Vis, M.; Klijn, F.; De Bruijn, K.M.; Van Buuren, M. Resilience Strategies for Flood Risk Management in the Netherlands. Int. J. River Basin Manag. 2003, 1, 33-40. [CrossRef]

4. Löschner, L.; Nordbeck, R. Switzerland's Transition from Flood Defence to Flood-Adapted Land Use-A Policy Coordination Perspective. Land Use Policy 2020, 95, 103873. [CrossRef]

5. Davoudi, S.; Crawford, J.; Mehmood, A. Planning for Climate Change: Strategies for Mitigation and Adaptation for Spatial Planners; Routledge: London, UK, 2009.

6. Roggema, R. Adaptation to Climate Change: A Spatial Challenge; Springer: Berlin/Heidelberg, Germany, 2009. [CrossRef]

7. Roggema, R. Swarm Planning Theory; Springer: Dordrecht, The Netherlands, 2012; Volume 48. [CrossRef]

8. United Nations. Transforming Our World: The 2030 Agenda for Sustainable Development; United Nations: New York, NY, USA, 2015.

9. Grafakos, S.; Gianoli, A.; Tsatsou, A. Towards the Development of An Integrated Sustainability and Resilience Benefits Assessment Framework of Urban Green Growth Interventions. Sustainability 2016, 8, 461. [CrossRef]

10. Tegart, W.J.M.; Sheldon, G.W.; Griffiths, D.C. AR1-Impacts Assessment of Climate Change; Australian Government Publishing Service: Canberra, Australia, 1990.

11. Kelly, P.M.; Adger, W.N. Theory and Practice in Assessing Vulnerability to Climate Change and Facilitating Adaptation. Clim. Chang. 2000, 47, 325-352. [CrossRef]

12. Lehner, B.; Döll, P.; Alcamo, J.; Henrichs, T.; Kaspar, F. Estimating the Impact of Global Change on Flood and Drought Risks in Europe: A Continental, Integrated Analysis. Clim. Chang. 2006, 75, 273-299. [CrossRef]

13. IPCC. Climate Change 2007: Impacts, Adaptation, and Vulnerability. Contribution of Working Group II to the Fourth Assessment Report of the Intergovernmental Panel on Climate Change; Parry, M.L., Canziani, O.F., Palutikof, J.P., Linden, P.J., van der Hanson, C.E., Eds.; Cambridge University Press: Cambridge, UK, 2007; Volume 26. [CrossRef]

14. United Nations Development Programme (UNDP). Mapping Climate Change Vulnerability and Impact Scenarios-A Guidebook for Sub-National Planners; United Nations Development Programme (UNDP): New York, NY, USA, 2010.

15. Forzieri, G.; Feyen, L.; Russo, S.; Vousdoukas, M.; Alfieri, L.; Outten, S.; Migliavacca, M.; Bianchi, A.; Rojas, R.; Cid, A. Multi-Hazard Assessment in Europe under Climate Change. Clim. Chang. 2016, 137, 105-119. [CrossRef]

16. Jana, A.B.; Hegde, A.V. GIS Based Approach for Vulnerability Assessment of the Karnataka Coast, India. Adv. Civ. Eng. 2016, 2016, 5642523. [CrossRef]

17. Katsman, C.; Hazeleger, W.; Sterl, A.; Beersma, J. Exploring High-End Climate Change Scenarios for Flood Protection of The Netherlands; KNMI: De Bilt, The Netherland, 2009; Volume 6. [CrossRef]

18. Barnard, P.L.; Erikson, L.H.; Foxgrover, A.C.; Hart, J.A.F.; Limber, P.; O'Neill, A.C.; van Ormondt, M.; Vitousek, S.; Wood, N.; Hayden, M.K.; et al. Dynamic Flood Modeling Essential to Assess the Coastal Impacts of Climate Change. Sci. Rep. 2019, 9, 1-13. [CrossRef]

19. IPCC. Climate Change 2001: Impacts, Adaptation, and Vulnerability. Contribution of Working Group II to the Third Assessment Report of the Intergovernmental Panel on Climate Change; McCarthy, J.J., Canziani, O.F., Leary, N.A., Dokken, D.J., White, K.S., Eds.; Cambridge University Press: Cambridge, UK, 2001.

20. Adger, W.N. Approaches to Vulnerability to Climate Change; The Centre for Social and Economic Research on the Global Environment (CSERGE): Norwich, UK, 1996.

21. Eriksen, S.H.; Kelly, P.M. Developing Credible Vulnerability Indicators for Climate Adaptation Policy Assessment. Mitig. Adapt. Strategy Glob. Chang. 2007, 12, 495-524. [CrossRef]

22. Eriksen, S.; Silva, J.A. The Impact of Economic Liberalisation on Climate Vulnerability among Farmers in Mozambique. In Proceedings of the IHDP Open Meeting, Montreal, QC, Canada, 16-18 October 2003.

23. Grasso, V.F.; Singh, A. Early Warning Systems: State-of-Art Analysis and Future Directions; Draft Report; UNEP: Nairobi, Kenya, 2011. [CrossRef] 
24. United Nations International Strategy for Disaster Reduction (UNISDR). Global Assessment Report on Disaster Risk Reduction, Making Development Sustainable: The Future of Disaster Risk Management; United Nations International Strategy for Disaster Reduction (UNISDR): Geneva, Switzerland, 2015; ISBN 9789211320282.

25. Hooijer, A.; Vernimmen, R.; Visser, M.; Mawdsley, N. Flooding Projections from Elevation and Subsidence Models for Oil Palm Plantations in the Rajang Delta Peatlands, Sarawak, Malaysia. Deltares Rep. 2015, $1207384,76$.

26. Takeuchi, K. Increasing Vulnerability to Extreme Floods and Societal Needs of Hydrological Forecasting. Hydrol. Sci. J. 2001, 46, 869-881. [CrossRef]

27. Klijn, F.; De Bruijn, K.; Ölfert, A.; Penning-Rowsell, E.C.; Simm, J.; Wallis, M. Flood Risk Assessment and Flood Risk Management: An Introduction and Guidance Based on Experiences and Findings of FLOODsite (an EU-Funded Integrated Project); FLOODsite; Deltares: Delft, The Netherlands, 2009; ISBN 9789081406710.

28. Khan, H.; Vasilescu, L.G.; Khan, A. Disaster Management Cycle-A Theoretical Approach. J. Manag. Mark. 2008, 6, 43-50.

29. European Commission. EU Floods Directive: What Is Flood Risk Management. Available online: https: //ec.europa.eu/environment/water/flood_risk/flood_risk.htm (accessed on 27 July 2019).

30. Kienholz, H.; Krummenacher, B.; Kipfer, A.; Perret, S. Aspects of Integral Risk Management in Practice-Considerations with Respect to Mountain Hazards in Switzerland. Österr. Wasser Abfallwirtsch. 2004, 56, 43-51.

31. Thieken, A.H.; Kreibich, H.; Müller, M.; Merz, B. Coping with Floods: Preparedness, Response and Recovery of Food-Affected Residents in Germany in 2002. Hydrol. Sci. J. 2007, 52, 1016-1037. [CrossRef]

32. Buurman, J.; Babovic, V. Adaptation Pathways and Real Options Analysis: An Approach to Deep Uncertainty in Climate Change Adaptation Policies. Policy Soc. 2016, 35, 137-150. [CrossRef]

33. Barnett, J.; Graham, S.; Mortreux, C.; Fincher, R.; Waters, E.; Hurlimann, A. A Local Coastal Adaptation Pathway. Nat. Clim. Chang. 2014, 4, 1103-1108. [CrossRef]

34. Siebentritt, M.; Halsey, N.; Smith, M.S. Regional Climate Change Adaptation Plan for the Eyre Peninsula. Prepared for the Eyre Peninsula Integrated Climate Change Agreement Committee; EPICCA: South Australia, Australia, 2014.

35. Reeder, T.; Ranger, N. How do You Adapt in an Uncertain World? Lessons from the Thames Estuary 2100 Project; World Resources Institute: Washington, DC, USA, 2010. [CrossRef]

36. Haasnoot, M.; Middelkoop, H.; Offermans, A.; van Beek, E.; van Deursen, W.P.A. Exploring Pathways for Sustainable Water Management in River Deltas in a Changing Environment. Clim. Chang. 2012, 115, 795-819. [CrossRef]

37. Ranger, N.; Millner, A.; Dietz, S.; Fankhauser, S.; Lopez, A.; Ruta, G. Adaptation in the UK: A Decision-Making Process; Environment Agency: Bristol, UK, 2010.

38. Wise, R.M.; Fazey, I.; Stafford Smith, M.; Park, S.E.; Eakin, H.C.; Archer Van Garderen, E.R.M.; Campbell, B. Reconceptualising Adaptation to Climate Change as Part of Pathways of Change and Response. Glob. Environ. Chang. 2014, 28, 325-336. [CrossRef]

39. Denton, F.; Wilbanks, T.J.; Abeysinghe, A.C.; Burton, I.; Gao, Q.; Lemos, M.C.; Masui, T.; O’Brien, K.L.; Warner, K. Climate-Resilient Pathways: Adaptation, Mitigation, and Sustainable Development. In Climate Change 2014: Impacts, Adaptation, and Vulnerability. Part A: Global and Sectoral Aspects. Contribution of Working Group II to the Fifth Assessment Report of the Intergovernmental Panel on Climate Change; Cambridge University Press: Cambridge, UK; New York, NY, USA, 2014; pp. 1101-1131.

40. Mechler, R.; Czajkowski, J.; Kunreuther, H.; Michel-Kerjan, E.; Botzen, W.; Keating, A.; McQuistan, C.; Cooper, N.; O'Donnell, I. Making Communities More Flood Resilient: The Role of Cost Benefit Analysis and Other Decision-Support Tools in Disaster Risk Reduction; International Institute for Applied Systems Analysis (IIASA): Laxenburg, Austria, 2014.

41. De Bruin, K.; Dellink, R.B.; Ruijs, A.; Bolwidt, L.; Van Buuren, A.; Graveland, J.; De Groot, R.S.; Kuikman, P.J.; Reinhard, S.; Roetter, R.P.; et al. Adapting to Climate Change in the Netherlands: An Inventory of Climate Adaptation Options and Ranking of Alternatives. Clim. Chang. 2009, 95, 23-45. [CrossRef]

42. Debels, P.; Szlafsztein, C.; Aldunce, P.; Neri, C.; Carvajal, Y.; Quintero-Angel, M.; Celis, A.; Bezanilla, A.; Martínez, D. IUPA: A Tool for the Evaluation of the General Usefulness of Practices for Adaptation to Climate Change and Variability. Nat. Hazards 2009, 50, 211-233. [CrossRef] 
43. Anguelovski, I.; Shi, L.; Chu, E.; Gallagher, D.; Goh, K.; Lamb, Z.; Reeve, K.; Teicher, H. Equity Impacts of Urban Land Use Planning for Climate Adaptation: Critical Perspectives from the Global North and South. J. Plan. Educ. Res. 2016, 36, 333-348. [CrossRef]

44. Stern, N. Stern Review: The Economics of Climate Change; Cambridge University Press: Cambridge, UK, 2007. [CrossRef]

45. Hallegatte, S.; Henriet, F.; Corfee-Morlot, J. The Economics of Climate Change Impacts and Policy Benefits at City Scale: A Conceptual Framework. Clim. Chang. 2011, 104, 51-87. [CrossRef]

46. Van Doorn-Hoekveld, W.J.; Goytia, S.B.; Suykens, C.; Homewood, S.; Thuillier, T.; Manson, C.; Chmielewski, P.J.; Matczak, P.; Van Rijswick, H.F.M. Distributional Effects of Flood Risk Management: A Cross-Country Comparison of Preflood Compensation. Ecol. Soc. 2016, 21, 26. [CrossRef]

47. Genovese, E. A Methodological Approach to Land Use-Based Flood Damage Assessment in Urban Areas: Prague Case Study; Office for Official Publications of the European Communities: Luxembourg, 2006.

48. Gould, I.J.; Wright, I.; Collison, M.; Bosworth, G.; Pearson, S.; Ruto, E. The Impact of Coastal Flooding on Agriculture: A Case-Study of Lincolnshire, United Kingdom. Land Degrad. Dev. 2020, 1-15. [CrossRef]

49. Baky, A.; Abdullah, M.; Islam, M.; Paul, S. Flood Hazard, Vulnerability and Risk Assessment for Different Land Use Classes Using a Flow Model. Earth Syst. Environ. 2019, 1-20. [CrossRef]

50. Wagemaker, J.; Leenders, J.; Huizinga, J.A.N. Economic Valuation of Flood Damage for Decision Makers in the Netherlands and the Lower Mekong River Basin. In Proceedings of the 6th Annual Mekong Flood Forum, Ho Chi Minh City, Vietnam, 17-18 May 2007; pp. 27-28.

51. Mechler, R.; The Risk to Resilience Study Team. The Cost-Benefit Analysis Methodology, from Risk to Resilience Working Paper No. 1; Moench, M., Caspari, E., Pokhrel, A., Eds.; ISET: Kathmandu, Nepal, 2008.

52. Merz, B.; Kreibich, H.; Schwarze, R.; Thieken, A. Review Article "Assessment of Economic Flood Damage". Nat. Hazards Earth Syst. Sci. 2010, 10, 1697-1724. [CrossRef]

53. Mechler, R. Reviewing Estimates of the Economic Efficiency of Disaster Risk Management: Opportunities and Limitations of Using Risk-Based Cost-Benefit Analysis. Nat. Hazards 2016, 81, 2121-2147. [CrossRef]

54. Aylett, A. Institutionalizing the Urban Governance of Climate Change Adaptation: Results of an International Survey. Urban Climb 2015, 14, 4-16. [CrossRef]

55. Fraser, A.; Kirbyshire, A. Supporting Governance for Climate Resilience: Working with Political Institutions; ODI: London, UK, 2017; Volume 517.

56. Keskitalo, E.C.H. (Ed.) Developing Adaptation Policy and Practice in Europe: Multi-Level Governance of Climate Change; Springer: Dordrecht, The Netherlands, 2010.

57. Bulkeley, H. Cities and Climate Change; Routledge: New York, NY, USA, 2013.

58. Bulkeley, H. Cities and the Governing of Climate Change. Annu. Rev. Environ. Resour. 2010, 35, 229-253. [CrossRef]

59. Moser, S.C.; Luers, A.L. Managing Climate Risks in California: The Need to Engage Resource Managers for Successful Adaptation to Change. Clim. Chang. 2008, 87 (Suppl. S1), 309-322. [CrossRef]

60. Jones, L.; Ludi, E.; Levine, S. Towards a Characterisation of Adaptive Capacity: A Framework for Analysing Adaptive Capacity at the Local Level; Overseas Development Institute: London, UK, 2010.

61. Yohe, G.; Tol, R.S.J. Indicators for Social and Economic Coping Capacity-Moving toward a Working Definition of Adaptive Capacity. Glob. Environ. Chang. 2002, 12, 25-40. [CrossRef]

62. Brooks, N.; Adger, W.N. Assessing and Enhancing Adaptive Capacity. In Adaptation Policy Frameworks for Climate Change: Developing Strategies, Policies and Measures; Cambridge University Press: Cambridge, UK, 2007; pp. 165-181.

63. Smit, B.; Wandel, J. Adaptation, Adaptive Capacity and Vulnerability. Glob. Environ. Chang. 2006, 16, 282-292. [CrossRef]

64. Adger, W.N.; Agrawala, S.; Mirza, M.M.Q.; Conde, C.; O’Brien, K.; Pulhin, J.; Pulwarty, R.; Smit, B.; Takahashi, K. Assessment of Adaptation Practices, Options, Constraints and Capacity; Parry, M.L., Canziani, O.F., Palutikof, J.P., van der Linden, P.J., Hanson, C.E., Eds.; Cambridge University Press: Cambridge, UK, 2007. [CrossRef]

65. Vincent, K. Uncertainty in Adaptive Capacity and the Importance of Scale. Glob. Environ. Chang. 2007, 17, 12-24. [CrossRef]

66. Mehrotra, S.; Natenzon, C.E.; Omojola, A.; Folorunsho, R.; Gilbride, J.; Rosenzweig, C. Framework for City Climate Risk Assessment. In Proceedings of the Fifth Urban Research Symposium, Marseille, France, 28-30 June 2009. 
67. United Nations. Living with Risk: A Global Review of Disaster Reduction Initiatives; United Nations: New York, NY, USA, 2004; Volume I.

68. Parsons, M.; Nalau, J.; Fisher, K.; Brown, C. Disrupting Path Dependency: Making Room for Indigenous Knowledge in River Management. Glob. Environ. Chang. 2019, 56, 95-113. [CrossRef]

69. Bulkeley, H.; Betsill, M.M. Cities and Climate Change: Urban. Sustainability and Global Environmental Governance; Routledge: London, UK, 2003. [CrossRef]

70. Kern, K. Governing Climate Change in Cities: Modes of Urban Climate Governance in Multi-Level Systems. Compet. Cities Clim. Chang. 2009, 2009, 171-196.

71. Simanjuntak, I.; Frantzeskaki, N.; Enserink, B.; Ravesteijn, W. Evaluating Jakarta's Flood Defence Governance: The Impact of Political and Institutional Reforms. Water Policy 2012, 14, 561-580. [CrossRef]

72. Lienert, J.; Schnetzer, F.; Ingold, K. Stakeholder Analysis Combined with Social Network Analysis Provides Fine-Grained Insights into Water Infrastructure Planning Processes. J. Environ. Manag. 2013, 125, 134-148. [CrossRef]

73. Dewulf, A.; Meijerink, S.; Runhaar, H. Editorial: The Governance of Adaptation to Climate Change as a Multi-Level, Multi-Sector and Multi-Actor Challenge: A European Comparative Perspective. Water Clim. Chang. 2015, 6, 1-8. [CrossRef]

74. Wamsler, C. From Risk Governance to City-Citizen Collaboration: Capitalizing on Individual Adaptation to Climate Change. Environ. Policy Gov. 2016, 26, 184-204. [CrossRef]

75. Moon, J.; Flannery, W.; Revez, A. Discourse and Practice of Participatory Flood Risk Management in Belfast, UK. Land Use Policy 2017, 63, 408-417. [CrossRef]

76. Bergsma, E. Changed Knowledge Requirements for Spatial Flood Governance. Ecol. Soc. 2016, 21, 1-10. [CrossRef]

77. Linnerooth-Bayer, J.; Scolobig, A.; Ferlisi, S.; Cascini, L.; Thompson, M. Expert Engagement in Participatory Processes: Translating Stakeholder Discourses into Policy Options. Nat. Hazards 2016, 81, 69-88. [CrossRef]

78. Harries, T.; Penning-rowsell, E. Victim Pressure, Institutional Inertia and Climate Change Adaptation: The Case of Flood Risk. Glob. Environ. Chang. 2011, 21, 188-197. [CrossRef]

79. Stead, D. Spatial Planning: Key Instrument for Development and Effective Governance with Special Reference to Countries in Transition; United Nations Office at Geneva: Geneva, Switzerland, 2008.

80. Fleischhauer, M. The Role of Spatial Planning in Strengthening Urban Resilience. In Resilience of Cities to Terrorist and other Threats; Springer: Dordrecht, The Netherlands, 2008; Volume Resilience, pp. 273-298.

81. Department of Infrastructure in Northern Ireland. Flood Maps NI. Available online: https://www. infrastructure-ni.gov.uk/topics/rivers-and-flooding/flood-maps-ni (accessed on 1 August 2020).

82. Environment Agency in England. Learn More about Food Risk. Available online: https://flood-warninginformation.service.gov.uk/long-term-flood-risk/map (accessed on 1 August 2020).

83. Scottish Environment Protection Agency. Flood Maps. Available online: https://www.sepa.org.uk/ environment/water/flooding/flood-maps/ (accessed on 1 August 2020).

84. Natural Resources Wales. Long Term Flood Risk Maps. Available online: https://naturalresources.wales/ evidence-and-data/maps/long-term-flood-risk/?lang=en (accessed on 1 August 2020).

85. Foundation Climate Adaptation Services. Climate Impact Atlas. Available online: https://www. klimaateffectatlas.nl/en/ (accessed on 1 August 2020).

86. New York-Connecticut Sustainable Communities Consortium. Coastal Climate Resilience: Urban Waterfront Adaptive Strategies; HUD Sustainable Communities Regional Planning Grant and the City of New York: New York, NY, USA, 2013.

87. Rotterdam Climate Initiative. Rotterdam: Climate Change Adaptation Strategy; Rotterdam Climate Initiative: Rotterdam, The Netherlands, 2013.

88. Hegger, D.L.T.; Driessen, P.P.J.; Dieperink, C.; Wiering, M.; Raadgever, G.T.T.; van Rijswick, H.F.M.W. Assessing Stability and Dynamics in Flood Risk Governance. Water Resour. Manag. 2014, 28, 4127-4142. [CrossRef]

89. Sayers, P.; Yuanyuan, L.; Galloway, G.; Edmund Penning-Rowsell, S.F.; Kang, W.; Yiwei, C.; Le Quesne, T. Flood Risk Management: A Strategic Approach; UNESCO: Paris, France, 2013.

90. Chiabai, A.; Hunt, A.; Galarraga, I.; Lago, M.; Rouillard, J.; De Murieta, E.S.; Tepes, A.; Troeltzsch, J.; Watkiss, P. Using Cost and Benefits to Assess. Adaptation Options; ECONADAPT: Bath, UK, 2015. 
91. Van Veelen, P.; Voorendt, M.; Van Der Zwet, C. Design Challenges of Multifunctional Flood Defences: A Comparative Approach to Assess Spatial and Structural Integration. Res. Urban Ser. 2015, 3, 275-292. [CrossRef]

92. Voorendt, M. Design Principles of Multifunctional Flood Defences; Delft University of Technology: Delft, The Netherlands, 2017. [CrossRef]

93. Wingfield, T.; Macdonald, N.; Peters, K.; Spees, J.; Potter, K. Natural Flood Management: Beyond the Evidence Debate. Area 2019, 1-9. [CrossRef]

94. Kang, S.-J.; Lee, S.-J.; Lee, K.-H. A Study on the Implementation of Non-Structural Measures to Reduce Urban Flood Damage: Focused on the Survey Results of the Experts. J. Asian Arch. Build. Eng. 2009, 8, 385-392. [CrossRef]

95. Coutinho-Rodrigues, J.; Sousa, N.; Natividade-Jesus, E. Design of Evacuation Plans for Densely Urbanised City Centres. In Institution of Civil Engineers-Municipal Engineer; Thomas Telford Ltd.: London, UK, 2016; Volume 169, pp. 160-172. [CrossRef]

96. Jamrussri, S.; Toda, Y. Available Flood Evacuation Time for High-Risk Areas in the Middle Reach of Chao Phraya River Basin. Water 2018, 10, 1871. [CrossRef]

97. Elsergany, A.T.; Griffin, A.L.; Tranter, P.; Alam, S. Development of a Geographic Information System for Riverine Flood Disaster Evacuation in Canberra, Australia: Trip Generation and Distribution Modelling. In Proceedings of the ISCRAM 2015 Conference Proceedings-12th International Conference on Information Systems for Crisis Response and Management, Krystiansand, Norway, 24-27 May 2015.

98. Tagg, A.F.; Chen, H.; Powell, D. The Use of Traffic Modelling to Inform a Flood Evacuation Policy for Lincolnshire and Norfolk. In Comprehensive Flood Risk Management; Schweckendiek, K., Ed.; Taylor \& Francis Group: London, UK, 2013; pp. 1541-1548.

99. World Health Organization (Regional Office for Europe). Flooding: Managing Health Risks in the WHO European Region; WHO: Geneva, Switzerland, 2017.

100. Walker, W.E.; Haasnoot, M.; Kwakkel, J.H. Adapt or Perish: A Review of Planning Approaches for Adaptation under Deep Uncertainty. Sustainability 2013, 5, 955-979. [CrossRef]

101. Haasnoot, M.; Kwakkel, J.H.; Walker, W.E.; ter Maat, J. Dynamic Adaptive Policy Pathways: A Method for Crafting Robust Decisions for a Deeply Uncertain World. Glob. Environ. Chang. 2013, 23, 485-498. [CrossRef]

102. Gersonius, B. The Resilience Approach to Climate Adaptation Applied for Flood Risk; IHE Delft Institute for Water Education: Delft, The Netherlands, 2012.

103. Van Veelen, P. Adaptive Strategies for the Rotterdam Unembanked Area: Synthesis Report; Knowledge for Climate Program Office: Utrecht, The Netherlands, 2013.

104. Van Veelen, P.C. Adaptive Planning for Resilient Coastal Waterfronts. A+BE| Archit. Built Environ. 2016, 19, $1-248$.

105. Thampapillai, D.J.; Musgrave, W.F. Flood Damage Mitigation: A Review of Structural and Nonstructural Measures and Alternative Decision Frameworks. Water Resour. Res. 1985, 21, 411-424. [CrossRef]

106. Water Resources Council. Regulation of Flood Hazard Areas to Reduce Flood Losses; US Government Printing Office: Washington, DC, USA, 1971.

107. Olshansky, R.B.; Johnson, L.A.; Horne, J.; Nee, B. Planning for the Rebuilding of New Orleans. J. Am. Plan. Assoc. 2008, 74, 273-287. [CrossRef]

108. Raaijmakers, R.; Krywkow, J.; van der Veen, A. Flood Risk Perceptions and Spatial Multi-Criteria Analysis: An Exploratory Research for Hazard Mitigation. Nat. Hazards 2008, 46, 307-322. [CrossRef]

109. De Bruin, K.; Goosen, H. Costs and Benefits of Adapting Spatial Planning to Climate Change: Lessons Learned from a Large-Scale Urban Development Project in the Netherlands. Reg. Environ. Chang. 2014, 14. [CrossRef]

110. Urban Floods Community of Practice (UFCOP). Land Use Planning for Urban Flood Risk Management; The World Bank (WB): Washington, DC, USA, 2017.

111. Sanghi, A.; Ramachandran, S.; de la Fuente, A.; Tonizzo, M.; Sahin, S.; Adam, B. Natural Hazards, UnNatural Disasters: The Economics of Effective Prevention; The World Bank: Washington, DC, USA, 2010.

112. Hochrainer-Stigler, S.; Kunreuther, H.; Linnerooth-Bayer, J.; Mechler, R.; Michel-Kerjan, E.; Muir-Wood, R.; Ranger, N.; Vaziri, P.; Young, M. The Costs and Benefits of Reducing Risk from Natural Hazards to Residential Structures in Developing Countries; University of Pennsylvania: Philadelphia, PA, USA, 2010.

113. White, I.; Richards, J. Planning Policy and Flood Risk: The Translation of National Guidance into Local Policy. Plan. Pract. Res. 2007, 22, 513-534. [CrossRef] 
114. Storbjörk, S. Governing Climate Adaptation in the Local Arena: Challenges of Risk Management and Planning in Sweden. Local Environ. 2007, 12, 457-469. [CrossRef]

115. Mileti, D. Disasters by Design: A Reassessment of Natural Hazards in the United States; Joseph Henry Press: Washington, DC, USA, 1999.

116. Deyle, R.E.; Chapin, T.S.; Baker, E.J. The Proof of the Planning Is in the Platting: An Evaluation of Florida's Hurricane Exposure Mitigation Planning Mandate. J. Am. Plan. Assoc. 2008, 74, 349-370. [CrossRef]

117. Francesch-Huidobro, M.; Dabrowski, M.; Tai, Y.; Chan, F.; Stead, D. Governance Challenges of Flood-Prone Delta Cities: Integrating Flood Risk Management and Climate Change in Spatial Planning. Prog. Plan. 2017, 114, 1-27. [CrossRef]

118. Mostert, E. Integrated Water Resources Management in the Netherlands: How Concepts Function. J. Contemp. Water Res. Educ. 2006, 135, 19-27. [CrossRef]

119. Ward, P.J.; Pauw, W.P.; Van Buuren, M.W.; Marfai, M.A. Governance of Flood Risk Management in a Time of Climate Change: The Cases of Jakarta and Rotterdam. Environ. Political 2013, 22, 518-536. [CrossRef]

120. Ran, J.; Nedovic-Budic, Z. Integrating Spatial Planning and Flood Risk Management: A New Conceptual Framework for the Spatially Integrated Policy Infrastructure. Comput. Environ. Urban Syst. 2016, 57, 68-79. [CrossRef]

121. Van Buren, A.; Ellen, G.J.; Warner, J.F. Path-Dependency and Policy Learning in the Dutch Delta: Toward More Resilient Flood Risk Management in the Netherlands? Ecol. Soc. 2016, 21, 43. [CrossRef]

122. Driessen, P.P.J.; Hegger, D.L.T.; Kundzewicz, Z.W.; van Rijswick, H.F.M.W.; Crabbé, A.; Larrue, C.; Matczak, P.; Pettersson, M.; Priest, S.; Suykens, C.; et al. Governance Strategies for Improving Flood Resilience in the Face of Climate Change. Water 2018, 10, 1595. [CrossRef]

123. Dabrowski, M. Boundary Spanning for Governance of Climate Change Adaptation in Cities: Insights from a Dutch Urban Region. Environ. Plan. C Political Space 2018, 36, 837-855. [CrossRef]

124. Wilby, R.L.; Keenan, R. Adapting to Flood Risk under Climate Change. Prog. Phys. Geogr. 2012, 36, 348-378. [CrossRef]

125. Runhaar, H.; Wilk, B.; Persson, Å.; Uittenbroek, C.; Wamsler, C. Mainstreaming Climate Adaptation: Taking Stock about "What Works " from Empirical Research Worldwide. Reg. Environ. Chang. 2018, 18, 1201-1210. [CrossRef]

126. Cumiskey, L.; Priest, S.J.; Klijn, F.; Juntti, M. A Framework to Assess Integration in Flood Risk Management: Implications for Governance, Policy, and Practice. Ecol. Soc. 2019, 24, 4. [CrossRef]

127. Davidse, B.J.; Othengrafen, M.; Deppisch, S. Spatial Planning Practices of Adapting to Climate Change. Eur. J. Spat. Dev. 2015, 1-21.

128. IPCC. AR5 Climate Change 2014: Impacts, Adaptation, and Vulnerability. Part. A: Global and Sectoral Aspects. Contribution of Working Group II to the Fifth Assessment Report of the Intergovernmental Panel on Climate Change; Field, C.B., Barros, V.R., Dokken, D.J., Mach, K.J., Mastrandrea, M.D., Bilir, T.E., Chatterjee, M., Ebi, K.L., Estrada, Y.O., Genova, R.C., et al., Eds.; Cambridge University Press: Cambridge, UK; New York, NY, USA, 2014.

(C) 2020 by the authors. Licensee MDPI, Basel, Switzerland. This article is an open access article distributed under the terms and conditions of the Creative Commons Attribution (CC BY) license (http://creativecommons.org/licenses/by/4.0/). 